\title{
A KUTATÁS-FEJLESZTÉS EGYES JELLEMZŐINEK TERÜLETI SZERKEZETE
}

\author{
(The regional structure of some characteristics of research and \\ development)
}

\section{DÖRY TIBOR}

Az elmúlt idószakban számos elemzés látott napvilágot a hazai $\mathrm{K}+\mathrm{F}$ szféra ráfordításainak, eredményeinek bemutatására (Inzelt 1996, OMFB 1993, 1995), de a statisztikai adatszolgáltatás hiányosságai miatt egyik tanulmány sem tartalmaz összemérhető adatokat ezen gazdálkodói kör területi folyamatainak nyomon követésére. Elgondolkodtató, hogy évek óta nem készült átfogó munka, amely a tudományos és technikai fejlődés az országban tapasztalható diszparitásait felszínre hozta volna, valamint ezek kiegyensúlyozására, netán ellensúlyozására területi programokat, támogatási formákat dolgozott volna ki. Igen, egyértelmủen támogatásokról kell beszélni, mert a fejlett ipari országokban, állami szinten is jelentős prioritást élveznek a technológiai fejlesztések, kutatási programok, a kutató szervezetek, kutatóhelyek és a vállalkozások közötti kooperációs hálózatok.

A kutatás-fejlesztés kiemelt gazdaságpolitikai kezelését az indokolja, hogy a tudomány és a technika a jólét megalapozója (Rába 1996). A kutatás támogatása szélesebbre nyitja a kaput az innováció számára, így a vállalkozások nővelhetik versenyképességüket. Jelen cikk arra tesz kísérletet, hogy a $\mathrm{K}+\mathrm{F}$ fellelhető területi forrásait, úgymint a $\mathrm{K}+\mathrm{F}$ szervezetek számát, a felsőoktatási kutatóhelyek számát, a KMÜFA támogatások mértékét, valamint a $\mathrm{K}+\mathrm{F}$ eredményeit, hangsúlyozottan a szabadalmi tevékenységet számba vegye és megjelenútse az egyes térségek között fennálló különbségeket, eltéréseket.

A kutatás-fejlesztés regionális megoszlását vizsgálva szembetűnỏ Budapest és az egyetemi városok $^{1}$ helyzete. Ez egyaránt elmondható a kutató-fejlesztó intézetek, kutatóhelyek, illetve a kutatók számáról, valamint az egyes területekre esó ráfordításokról. Az ország e téren is erósen centralizált, Budapest központú, a vidéki egyetemi városok csak kisebb jelentőségüek. Ez a folyamat azonban, ha kis mértékben is, de megtörni látszik. A vidéki egyetemek, fơiskolák (fỏvárosi kollégáikhoz hasonlóan) egyéni útkereséssel próbálják oktatói és - megbízások alapján - kutatói tevékenységüket diverzifikálni, minél szélesebb területre kiterjeszteni. Korábban a vállalatok számára végzett és biztos bevételt jelentő kutatási feladatok száma és volumene eröteljesen visszaesett a vállalatok háttérbeszorult fejlesztési tevékenysége következtében. Ezen apadó bevételek és az állami költségvetés fokozódó elvonása ellentételezésére a felsőoktatási intézmények is vállalkozói tevékenységet kényszerülnek folytatni. Ennek keretében technológiai transzfer és/vagy innovációs központokat (Debrecen, Miskolc, Szeged, Győr) próbálnak létrehozni, amely létesítmények feladata elsősorban az elméleti kutatási eredmények gyakorlatban történő megvalósításának megkönnyítése, implementációja, valamint az alkalmazott kutatási témák bevonása az oktatásba, képzésbe. 
A tudományos kutatás és fejlesztés területi adatai utoljára 1986-ban jelentek meg, azóta nem készült átfogó statisztika, amely teljes körüen bemutatta volna a $\mathrm{K}+\mathrm{F}$-fel foglalkozó szervezetek (kutatóintézetek, felsőoktatási intézmények és vállalatok) fontosabb mutatóit, úgymint a $\mathrm{K}+\mathrm{F}$ foglalkoztatottak létszámát (kutató és segédszemélyzet), a ráfordítások összegét. Ezen adatok ismeretében lenne mód olyan összehasonlítások megtételére, hogy a piacgazdaságra történỏ átmenetben pontosan hogyan alakult a $\mathrm{K}+\mathrm{F}$-szektor területi szerkezetének átrendeződése, az ország mely területein nőtt, illetve csökkent leginkább az effajta tevékenység, foglalkoztatás.

\section{TÁBLÁZAT}

A kutatás-fejlesztés bázisa (1990-1993)

(The basis of the R\&D, 1990-1993)

\begin{tabular}{|l|r|r|r|r|r|r|}
\hline \multirow{2}{*}{ Terület } & \multicolumn{2}{|c|}{ Kutatóhelyek száma* } & \multicolumn{2}{c|}{$\begin{array}{c}\text { Kutatók száma } \\
\text { összesen }(f o ̈)\end{array}$} & \multicolumn{2}{c|}{$\begin{array}{c}\text { K+F ráfordítások } \\
\text { (millió Ft)** }\end{array}$} \\
\cline { 2 - 7 } & \multicolumn{1}{|c|}{1990} & \multicolumn{1}{c|}{1993} & \multicolumn{1}{c|}{1990} & \multicolumn{1}{c|}{1993} & \multicolumn{1}{c|}{1990} & \multicolumn{1}{c|}{1993} \\
\hline Budapest & 616 & 608 & 19.023 & 13.640 & 19.533 & 22.390 \\
Egyetemi városok & 441 & 533 & 7.344 & 6.795 & 5.004 & 6.409 \\
Egyéb városok & 199 & 239 & 3.889 & 2.577 & 4.081 & 3.823 \\
\hline Ósszesen & 1.256 & 1.380 & 30.256 & 23.012 & 28.618 & 32.622 \\
\hline
\end{tabular}

Forrás: Tudomảnyos kutatás és kísérleti fejlesztés 1993. KSH

* A kutató-fejlesztö helyek számába értendök a $\mathrm{K}+\mathrm{F}$ intézetek, a felsőoktatási, vállalati és egyéb kutatóhelyek.

** A ráforditások értéke nominál értéken.

A $\mathrm{K}+\mathrm{F}$ bázisát tekintve (1. táblázat) érzékelhetỏ a kutatóhelyek számának enyhe bóvülése, ami az egyetemi városokban elérte a $20 \%$-ot. Ennek hátterében elsősorban a felsőoktatási és nem a vállalati kutatóhelyek számának emelkedése állt. A tudományos kutatók és fejlesztók legnagyobb mértékben a kutatóintézeteket és a vállalati kutatóhelyeket hagyták el. E két kategóriánál a létszám leépülés mértéke meghaladta az $50 \%$-ot, teljes munkaidejü foglalkoztatottakra számítva pedig a 32\%-ot. A ráfordítások összege a felsőoktatási kutatóhelyeken jelentősen (58\%-kal) nött, azonban a többi szervezeti típusnál az 1990-es bázisévhez viszonyítva nem változott. Az inflációt figyelembe véve az 58\%-os növekedés reálértéken csak szinten tartást jelentett a felsőoktatási $\mathrm{K}+\mathrm{F}$ finanszírozásában, a többi területen pedig egyértelmủ és jelentős forrásbeszükülésnek lehettünk tanúi.

\section{A $K+F$ szervezetek számának változása}

A statisztikai kiadványok közlik ugyan a kutató-fejlesztỏ helyek jegyzékét, de bővebb adatokat nem árulnak el a vállalatokra vonatkozólag, így saját adatfeldolgozással csupán a jogi személyiséggel rendelkező szervezetek számának változását sikerült nyomon követni (2. táblázat).

Az 1990-es évhez képest jelentős dinamikát mutat a $\mathrm{K}+\mathrm{F}$ vállalkozások számának országszerte megfigyelhetỏ növekedése. Nógrád megyét leszámítva kivétel nélkül mindenütt jelentós számú új, fejlesztéssel foglalkozó szervezet jött létre. A már meglévőkhöz képest és nem abszolút értékben jelentős, hiszen megyénként kevesebb, mint egy tucat, maximum két tucat $\mathrm{K}+\mathrm{F}$, de nem feltétlenül high-tech(!) vállalkozás önmagában 
rendkívül alacsony, a vállalkozások számához mérten szinte elhanyagolható innovációs potenciált képez. Valószínủ, hogy a $\mathrm{K}+\mathrm{F}$ vállalkozások bövülésének indoka a nagyvállalatok leépưlt $\mathrm{K}+\mathrm{F}$-részlegeinek és az ágazati, illetve a felsỏoktatási kutatóhelyeket elhagyó és önálló vállalkozást kezdő kutatók ưj típusú egzisztencia keresésében rejlik.

\section{TÁBLÁZAT}

A kutatás-fejlesztéssel foglalkozó szervezetek számának változása 1990-1994

(The change of the number of the R\&D institutions, 1990-1994)

\begin{tabular}{|l|c|c|c|}
\hline \multicolumn{1}{|c|}{ Régió } & 1990 & 1994 & Változás 1994/1990 \\
\hline Észak-Dunántúl & 36 & 78 & 2,17 \\
\hline Észak-Magyarország & 17 & 33 & 1,94 \\
\hline Észak-Alföld & 13 & 30 & 2,31 \\
\hline Dél-Alföld & 15 & 32 & 2,13 \\
\hline Központ & 23 & 57 & 2,48 \\
\hline Dél-Dunántúl & $\mathbf{1 7}$ & 38 & 2,24 \\
\hline Budapest & $\mathbf{2 6 9}$ & 639 & 2,38 \\
\hline Ország összesen & 390 & 907 & 2,33 \\
\hline
\end{tabular}

Forrás: KSH CIM-KE adatbázis 1990. dec.31., 1994. dec. 31.

Régiók szerint elemezve az adatokat az ország innovációs erőforrásainak meghatározó hányadát adó Budapestet követően kitủnik az Észak-Dunántúl és a Központ (Pest megye) kiemelkedỏ szerepe. A két régiót leszámítva másutt kiegyensúlyozottan alacsony a fejlesztést végző szervezetek száma, a közel hasonló értékek mögött azonban megyék szerint jelentős eltérések tapasztalhatók. Pest megyét kővetően legtöbb $\mathrm{K}+\mathrm{F}$ vállalkozás Győr-Moson-Sopron, Borsod-Abaủj-Zemplén, Baranya, Hajdú-Bihar, Veszprém és Fejér, majd Csongrád megyében található, tehát a regionális központokban a legeróteljesebb a kutatás iránti gazdálkodói elkötelezettség. A növekedés üteme Székesfehérváron volt a legnagyobb, ahol a négy évvel korábbi állapothoz képest több, mint ötször annyi $\mathrm{K}+\mathrm{F}$ vállalkozás müködött, de a dinamikus centrumok közé tartozik Miskolc, Debrecen, Szeged, Gödöllö, Pécs, Veszprém és Győr is. Nem mehetünk el amellett, hogy ne hangsúlyozzuk a vidék lemaradását, fejlesztési potenciáljának szerényebb volumenét a föváros dominanciájához képest, mivel Budapesten található az ország összes $\mathrm{K}+\mathrm{F}$ szervezetének valamivel több, mint kétharmada és ez a vizsgált időszakban még valamelyest (68\%-ról 70\%-ra) nőtt is.

\section{Felsöoktatási kutatóhelyek}

A felsőoktatás nem csupán a $\mathrm{K}+\mathrm{F}$-szektorban elfoglalt vezetỏ helye, hanem a technológiailag fejlettebb termékeket és versenyképes szolgáltatásokat megszervezó és elöállító, valamint az ezek értékesítését végzö szakemberek képzésében elfoglalt meghatározó pozíciója miatt van hatással a belsỏ regionális fejlödésre (Horváth 1994). Éppen ezért, ha összehasonlító adatokat nem is tartalmaz a statisztika, nem mehetünk el a felsőoktatás kutatási potenciáljának értékelése mellett. Az újabb KSH kiadványok (1993tól) már csak az egyes intézményekre vonatkozó adatokat (amelyben benne foglaltatnak a kihelyezett egyetemi és föiskolai karok is) közlik, igy hát ezekre hagyatkozva kellett valamiféle terủletiséget tükröző összesítést generálni (1., 2. ábra). 
1. ÁBRA

A felsóoktatási kutatóhelyek számának változása (1990-1993)

(The changes of number of $R \& D$ places in high education, between 1990,1993)

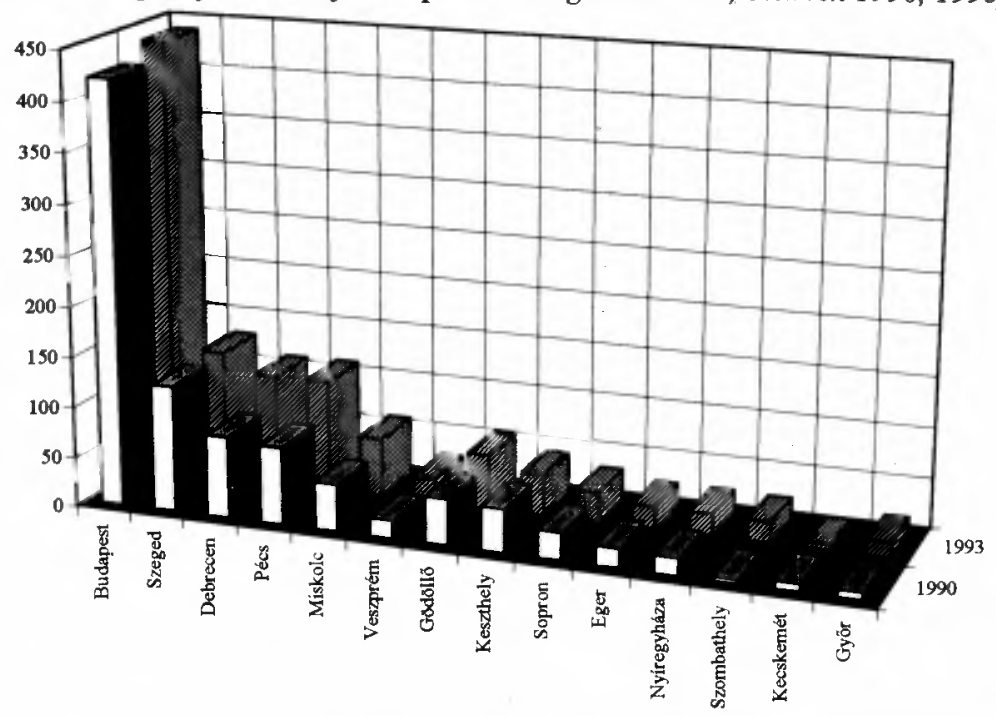

2. ÁERA

A felsöoktatósi kutatóhelyek tényleges létszáma Budapest nélkül (1990-1993)

The real number of $R \& D$ places in high education, without Budapest, 1990-1993)

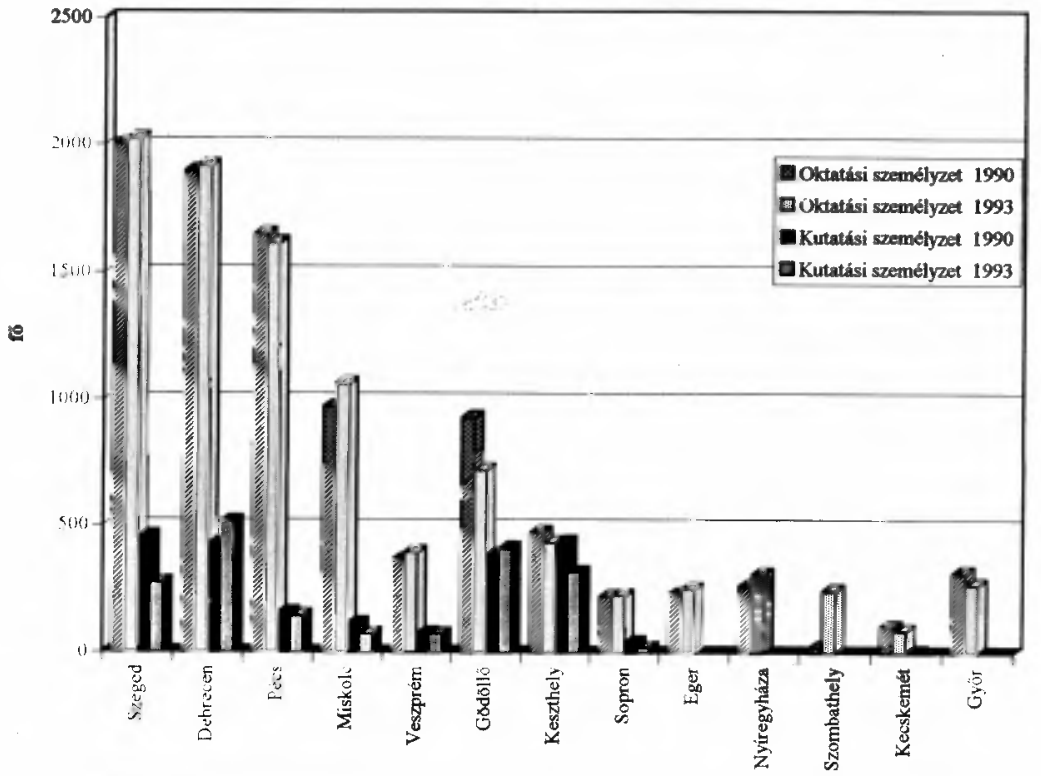


Az ábrák bemutatásának célja a felsỏoktatási kutatóhelyek számának és létszámadatainak területi bontásban való megjelenítése, a három év alatt végbement változások ábrázolása, illetve az oktatási és kutatási személyzet eltérő nagyságrendjének érzékeltetése azokban az intézményekben, ahol egyáltalán van kutatási tevékenység. Fontos leszögezni azonban, hogy a felsőoktatásban csökkent a legkevésbé a kutatóhelyek, kutatók száma, illetve a felsőoktatásra fordított kiadások még szerény mértékben növekedtek is. Az ábrákon csak az "anyaegyetem, - föiskola" székhelyéhez rendelt adatok jelennek meg, de ennek ellenére jól láthatók az egyetemi városok között is meglévő fejlesztői, kutatói potenciál különbségek, amik természetesen rányomják bélyegüket a hiányzó vagy rendkivül alacsony mértékü vállalati $\mathrm{K}+\mathrm{F}-\mathrm{re}$ is. Érdekes kettősségre utal, hogy a $\mathrm{K}+\mathrm{F}$ vállalkozások száma is éppen az egyetemi centrumokban nótt a legdinamikusabban (2. táblázat). Ennek magyarázata lehet, hogy volt, vagy éppen fóállású egyetemi, kutatóintézeti kutatók alapítanak gazdasági szervezetet fejlesztési eredményeik megvalósítására és így teremtve kapcsolatot a munkahelyen folytatott alap- és a vállalkozói életben megvalósított alkalmazott kutatás között.

\section{KMÜFA támogatások}

A bemutatott helyzetkép és a fejlesztési tevékenység mértékének alátámasztására megvizsgáltuk a Központi Müszaki Fejlesztési Alapból a gazdálkodó szervezetek számára folyósított támogatások területi megoszlását.

A Központi Müszaki Fejlesztési Alap (KMÜFA) az a finanszírozási eszköz, amelyet a kormány technológiapolitikájának érvényesítéséhez használnak fel. Kezeléséért az Országos Müszaki Fejlesztési Bizottság a felelós. Az alapot 1994-ig az elözö évi vállalkozási nyereségadó 4,5 százalékos hozzájárulása finanszírozta. 1995 -ig nemcsak a $\mathrm{K}+\mathrm{F}$ finanszírozására volt felhasználható, hanem K+Ffel kapesolatos beruházásra, kísérleti projektek kidolgozására, információ vásárlására is lehetett fordítani. 1995-töl azonban a források beszúkủlése és az állami elvonás miatt új rendszerú pályázatokat hirdettek meg ("Alkalmazott $K+F$ pályázat", "Exportképes termékek múszaki fejlesztési pályázata", valamint "A müszaki fejlesztés társadalmi feltételei javításảnak támogatására"). Azóta megjelent már a következő "Alkalmazott $\mathrm{K}+\mathrm{F}$ pályázat" is, valamint folyamatosan lehet az "Exportképes termékek müszaki fejlesztési pályázatra" projekteket beadni.

A 3. ábra megyék szerinti bontásban követi nyomon az OMFB-hez beadott és elfogadott KMÜFA pályázatok alapján megítélt támogatások összegének alakulását.

Jól látható, hogy a Központ és az Észak-Dunántúl megyéi az országos átlag feletti mértékben részesültek müszaki fejlesztési támogatásban. A többi régióban általánosan alacsony volt a pályázati aktivitás, csak a már többször emlitett egyetemi centrumokban mủködő vállalkozások, kutatóhelyek nyertek az országos átlagnál nagyobb összegủ KMÜFA támogatást. Kiugró összegú addicionális fejlesztési forráshoz jutottak Pest, Borsod-Abaủj-Zemplén, Hajdú-Bihar, Györ-Moson-Sopron és Veszprém megye pályázói.

Évek szerint tekintve szembetünö a kezdeti, 1991-es évben jóváhagyott összegek mértéke, majd a volumen folyamatos csökkenése. Ennek két oka van: egyrészt a jóváhagyott projektek általában három évre szóltak, így nem minden esetben nyújtottak be évente újabb pályázatot a gazdálkodók, hanem megvárták kutatási programjuk kifutását, majd ezt követően kérvényeztek további támogatást, amelynek eredménye az ábrán észrevehető jelentős hullámzás. Másrészt a rendelkezésre álló és elosztható források jelentősen beszúkültek, az 1991-es 14,04 milliárd forintos kezdeti értékröl 1994-re nominál értéken számitva 11,18 milliárd forintra apadt a KMÜFA összege. 


\section{3. ÁBRA}

Elfogadott KMÜFA pályázatok 1991-1994 között (ezer Ft) (Budapest nélkül) (The accepted KMÜFA applications between 1991-1994, without Budapest, thousand Ft)

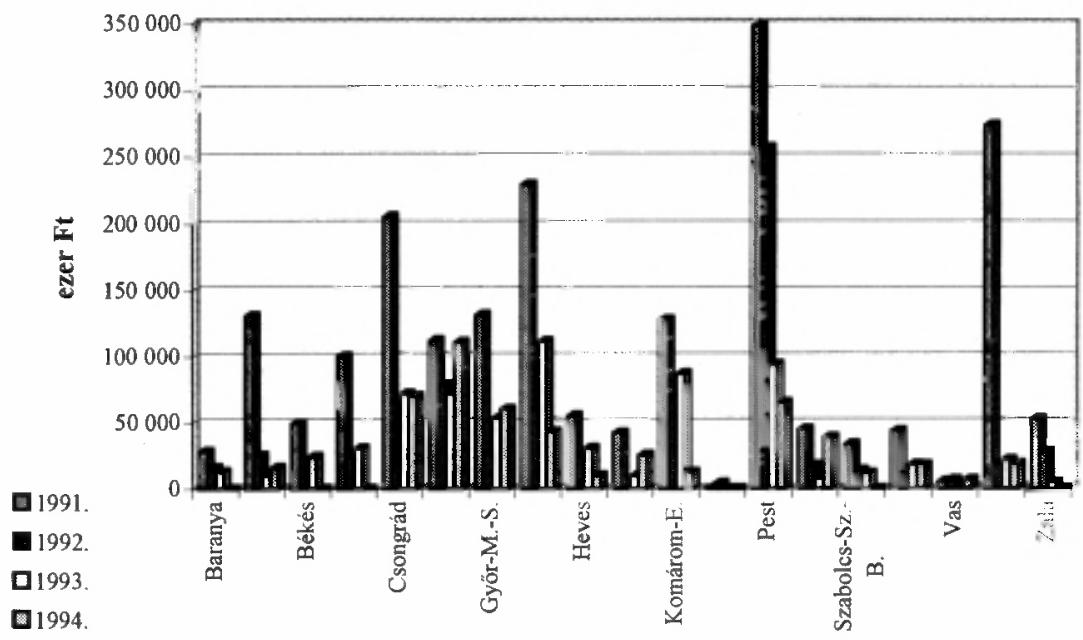

Forrás: OMFB, egyéni adatgyủjtés

Az említett ingadozás ennek köszönhetően jóval visszafogottabbá vált és ha az 1995-ös esztendó adataival is kiegészitenénk a bemutatottakat, akkor még szerényebb értékeket tapasztalhatnánk.

Az elfogadott pályázatokat szakterületenként áttekintve meghatározónak mondható az ipari és infrastrukturális fejlesztésre fordított összegek nagysága, ami az összes elfogadott támogatás 66\%-át tette ki. Ezen belül Hajdú-Bihar, Pest, Fejér, Komárom-Esztergom, Györ-Moson-Sopron és Borsod-Abaúj-Zemplén megye alkották az élbolyt a minden területen elsőséget kivívott Budapest mögött. A mezógazdasági célú $\mathrm{K}+\mathrm{F}$ területén Pest, Fejér és Csongrád megye több, mint kétszer akkora forrást használhatott fel, mint az utánuk következó megyék. Végül a környezetvédelem és egészségủgy ágazatokban Komárom-Esztergom, Pest, Csongrád, Zala és Veszprém megye volt a legaktívabb forrásszerzó.

A teljesség igénye nélkül szólni kell a sereghajtó, a $\mathrm{K}+\mathrm{F}$ tevékenységekre legkevesebb állami hozzájárulást megpályázó területekról is. Nógrád, Vas és Szabolcs-Szatmár-Bereg megye minimális támogatást kapott a KMÜFÁ-ból, melyben legmeglepőbb Vas megye helyezése, hiszen a nyugati határszél mellett elhelyezkedő megye jelentős gazdasági eredményekkel büszkélkedhet az utóbbi pár évben (vegyes vállalatok számának növekedése, alacsony munkanélküliségi ráta).

A vállalkozások számát fịgyelembe vevő összehasonlítás (3. táblázat) a jogi személyiségü, ill. a jogi személyiség nélküli gazdasági szervezetekre, valamint az egyéni 
Tér és Társadalom, 10. 1996. 2-3. 157-165. p.

vállalkozásokra vetítve adja meg az elnyert támogatások összegét ${ }^{2}$. Budapestet nem számítva, az Észak-Dunántúl és az Észak-Alfơld az országos átlagnál nagyobb arányban részesedik a KMỨFA támogatásokból. A régiókon belül az elózőeknek megfeleló eltérések természetesen itt is megmutatkoznak.

\section{TÁBLÁZAT}

A KMÜFA támogatás összege gazdasági szervezet típusonként (1991-1994) (The amount of the KMÜFA supports by economic organisations, 1991-1994)

\begin{tabular}{|l|c|c|c|}
\hline \multicolumn{1}{|c|}{ Régiók } & $\begin{array}{c}\text { l jogi szem. gazd. } \\
\text { szerv.-re jutó } \\
\text { KMÜFA (eFt) }\end{array}$ & $\begin{array}{c}\text { 1 jogi szem. nélkuuli } \\
\text { gazd. szerv.re jutó } \\
\text { KMÜFA (eFt) }\end{array}$ & $\begin{array}{c}\text { l egyéni } \\
\text { vállalkozóra jutó } \\
\text { KMÚFA (eFt) }\end{array}$ \\
\hline Észak-Dunántúl & 129,71 & 89,88 & 10,19 \\
\hline Észak-Magyarország & 55,86 & 43,25 & 3,96 \\
\hline Észak-Alföld & 94,91 & 57,48 & 7,26 \\
\hline Dél-Alfóld & 87,55 & 47,45 & 7,48 \\
\hline Kozpont & 133,80 & 105,44 & 13,06 \\
\hline Dél-Dunántúl & 57,24 & 37,30 & 3,62 \\
\hline Budapest & 225,93 & 176,26 & 37,43 \\
\hline
\end{tabular}

Forrás: OMFB és KSH adatok alapján egyéni számítás

\section{A megadott szabadalmak száma}

A vállalkozói és az innovációs aktivitás egyik fokméröjeként, a $\mathrm{K}+\mathrm{F}$ szektor eredményeinek bemutatására megvizsgáltuk a szabadalmi bejelentések számát területi bontásban ${ }^{3}$. Általánosan elmondható, hogy két különböző irányzatot figyelhetünk meg a magyarországi szabadalmi kérelmek vizsgálatakor. Elöször, a magyar feltalálók által benyújtott kérelmek száma csökkent a gazdasági szerkezetváltás és a $\mathrm{K}+\mathrm{F}$ kiadások visszaesése következtében. Másodszor, a külfơldi feltalálók által benyújtott kérelmek száma ugrásszerúen megnỏtt, ami jól mutatja a magyar $\mathrm{K}+\mathrm{F}$ piac nemzetközivé válását (Inzelt 1996).

A megadott szabadalmak száma régiónként és megyénként a már vizsgált KMÜFA-hoz hasonlóan alakult (4. ábra) azzal a különbséggel, hogy ez esetben az Észak-Dunántúl és Budapest fej-fej mellett haladt, míg a Központ az eröteljesen innovatív Dél-Alföld mögött a negyedik a régiók sorrendjében. Első ránézésre is szembetünő a szabadalmi aktivitás évenként csökkenó intenzitása, ami a korábban leirtak alapján nem meglepö.

Ezen tendencia alól egyedül talán Budapest a kivétel, amely kisebb megtorpanással (1991-92) képes volt fenntartani aktivitását. A megyék versenyében a pozitív csúcsot ez esetben Pest, Hajdú-Bihar, Csongrád és Veszprém, míg a negativ csúcsot Nógrád mellett Vas megye jelenti. A megyéken belül elsösorban az egyetemnek, illetve föiskolának btthont adó városok (Gödöllő, Debrecen, Szeged, Veszprém) a dominánsak. Kivételt képezek azonban az olyan kisebb települések, amelyeken egyedülálló, szenvedélyes feltalálók laknak és öket leszámítva nem jellemzö a feltalálói tevékenység, az újdonság keresése. Ennek következtében nagyon nehéz arról beszélni, hogy az egyes szabadalmaknak, találmányoknak mi a további sorsa, hogyan hasznosulnak. 


\section{4. ÁBRA}

A megadott szabadalmak száma régiónként (1990-1994)

(The number of granted patents by regions, 1990-1994)

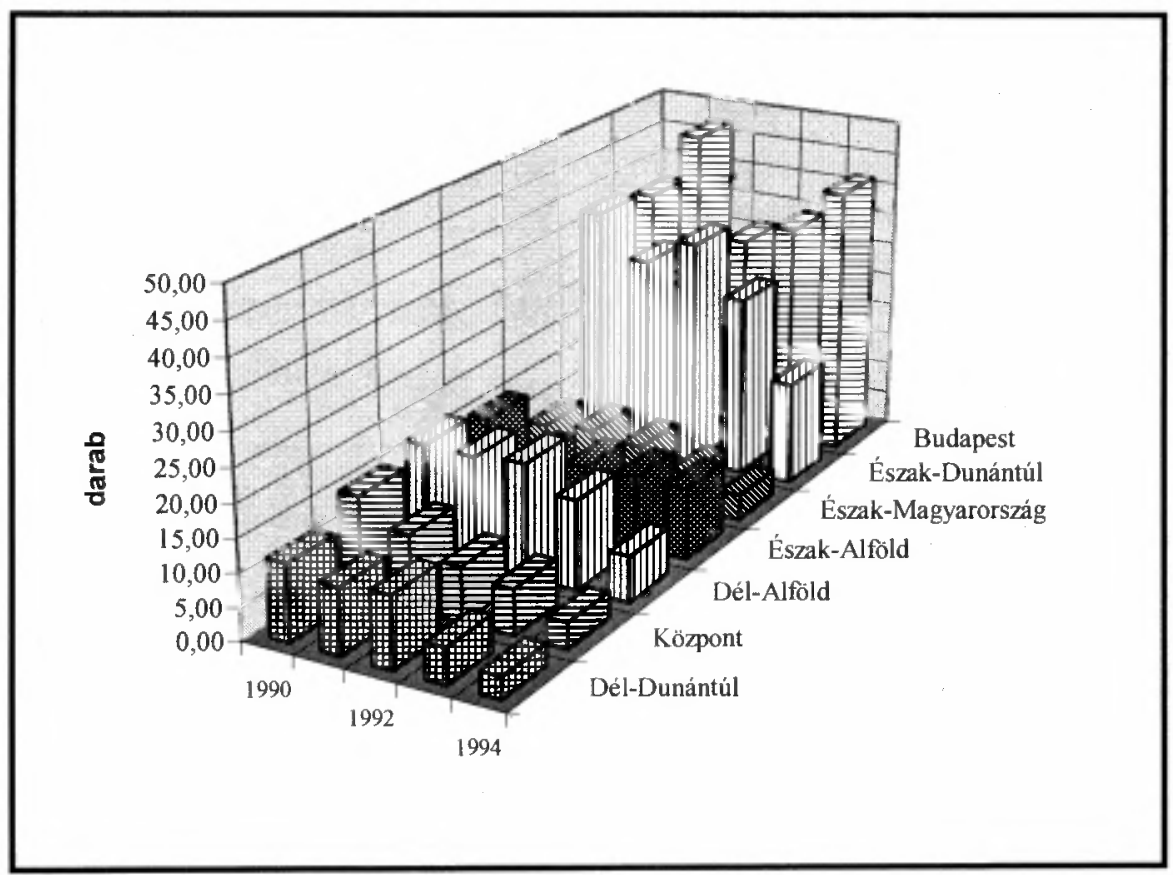

Forrás: OTH, saját adatfeldolgozás

\section{Összegzés}

A $\mathrm{K}+\mathrm{F}$ szféra bemutatott néhány jellemző adata egyértelmủen jelzi az egykor szebb napokat látott magyar tudományos kutatási és mủszaki fejlesztési élet sorvadását, forrásainak jelentösen csökkenö volumenét. Ennek egyenes következménye az egyre kevesebb hozzáadott szellemei terméket tartalmazó produktum, tudásigényes termék és eljárás. Megdöbbentően csökken (és ez sajnos tendencia!) a hazai tudományos élet aktív szakembereinek, kutatónak és tudósainak száma, miközben jelentősen érvényesül a "belső agyelszivás", egykori kutatók jól fizetett állásokat vállalnak az üzleti életben, fóként vegyes és külföldi tulajdonú vállalkozásoknál. Jól képzett szakemberek, minősített kutatók nélkül pedig óhatatlanul visszaesik az új hazai eredmények száma, a külföldi eredmények adaptációjának, továbbfejlesztésének esélye. Erre mindenféleképpen fel kell, hogy figyeljenek a döntéshozók és a gazdaságpolitika felelös irányitói, nehogy túl késö legyen a hazai szellemi és tudományos élet újraélesztésének kísérlete. 


\section{Jegyzetek}

' A KSH kiadványok egyetemi városnak tekintik: Debrecen, Miskolc, Pécs, Szeged, Veszprém, Sopron, Keszthely és Gơdöllỏ városokat.

2 A jogi személyiségủ, jogi személyiség nélkủli gazdasági szervezetek, valamint az egyéni vállalkozások számának figyelembevételekor a KSH 1993. évi adatközlését vettuk alapul.

3 Az Országos Találmányi Hivatal rendelkezésre bocsátotta adatbázisát olyan formában, hogy a bejelentést, illetve a szabadalmi oltalmat kapott személyek lakóhelyét adta meg a feltaláló tulajdoni hányadának figyelembevételével. Gyakorlatilag, ha két feltaláló 50-50 százalékban formált jogot a szabadalomra és különbőzö településen laktak, mindegyik településhez 0,5-0,5 értéket rendelt.

\section{Irodalom}

OECD tanulmány (1993) Tudomány-, technológia és innovációpolitika Magyarországon. OMFB. Budapest Horváth Gyula (1994) A Dél-Dunántúl nemzetkőzi versenyképességének elöfeltétele, a technikai megújulás. Tér és Társadalom. 1-2,37-58, o.

Innovációs folyamatok a magyar gazdaságban. OMFB. Budapest, 1995.

Inzelt Annamária (1996) A ráfordítások és eredmények a hazai K+F-szférában. Külgazdaság. 1. 55-73. o.

Rába András (1996) Technológiapolitikai irányzatok a fejlett ipari országokban. Külgazdaság. 1. 45-57. o.

\section{Abstract}

Several analyses have been made recently on the inputs and results of the Hungarian $\mathrm{R}+\mathrm{D}$ sector, however, owing to the deficiencies of the provision of statistical data, none of these studies contain comparable data which could help us examine the spatial processes of the economic sector. For several years no comprehensive work has been carried out which would highlight the disparities of scientific and technical development in Hungary and work out regional programmes and support forms to equalise, or even compensate these. We do have to talk about support, as in the developed industrial countries technological developments, research programmes, and co-operative networks between research organisations, research workshops and businesses are given a significant priority at state level, too.

A special treatment of research and development is justified by the fact that science and technics are the establishment of well-being. Supports for research help the adaptation of innovations so that businesses can increase their competitiveness. The article aims at enumerating and highlighting the present differences and disequilibria between the individual regions. 